\title{
Audits in a Textile Company and Advantages
}

\section{Bir Tekstil İşletmesinde Denetimler ve Avantajları}

\author{
Mine Seçkin ${ }^{1}$ (D, Feden $\operatorname{Koç}^{2}$ (E), Ahmet Çağdaş Seçkin ${ }^{3}$ (1)
}

'Balta Group, Uşak, Turkey

${ }^{2}$ (Lecturer), Usak University, Karahalli Vocational School, Department of Office Management and Administrator Assistantship,Ușak, Turkey

${ }^{3}$ (Asst. Prof.), Adnan Menderes University, Faculty of Engineering, Computer Engineering, Aydın, Turkey

ORCID: M.S. 0000-0002-9564-1534 F.K. $0000-0003-4413-5188$ A.Ç.S. 0000-0002-9849-3338

Corresponding author: Mine SEÇKIN

Balta Group, Uşak, Turkey

E-mail address: mine1seckin@gmail.com

Submitted: 24.10 .2020

Revision Requested: 07.01.2021

Last Revision Received: 25.01.202

Accepted: 02.02.2021

Published Online: 31.05 .2021

Citation: Seckin, M., Koc, F., Seckin, A. C. (2021). Audits in a textile company and advantages. Acta Infologica, 5(1), 99-116. https://doi.org/10.26650/acin.815934

\begin{abstract}
Textile companies must develop strategies to survive in today's competitive and volatile world and flexibly adapt these strategies to today's conditions. In this competitive environment, audits conducted by an internal or external auditor, especially at the request of the customer, enable companies to differentiate themselves from other companies. Audits performed by companies can be classified in various ways. In this study, audit types are classified into internal and external audits depending on the type of auditor. If the audit is conducted by a person working in a company with a contract of pay, it is an internal audit, if not, it is an external audit. The principles and benefits of the audit to the company are explained in the study. In this study, a simulation was prepared to investigate the effect of audit frequency, internal interaction and number of employees in the company on the improvement of the company. In the prepared simulation, relevant changes were processed according to internal parameters on daily basis. As a result, it was found that with sufficient recovery of all parameters within the company, the highest improvement success is achieved when the audit frequency is conducted at least every 3 months. Future studies, information on how the developing information technologies and artificial intelligence provide convenience and perspective for audits are presented.

Keywords: Audit, GMP audit, Quality management system, Environment management system, Remote auditing, Online auditing
\end{abstract}

\section{Öz}

Tekstil fabrikaları günümüzün rekabetçi ve değişken dünyasında ayakta kalabilmek için stratejiler geliştirmeli ve bu stratejileri esnek bir şekilde günümüz koşullarına uyarlamalıdır. Bu rekabet ortamında özellikle müşteri isteği üzerine iç veya dış denetçi tarafından yapılan denetimler işletmelerin diğer işletmelerden bir adım öne çıkmasını sağlamaktadır. Şirketlerin aldığı denetimler çeşitli şekillerde sınıflandırılabilir. Bu çalışmada denetim türleri denetçi türüne göre iç ve dış denetim olarak sınıflandırılmıştır. Denetim, bordro sözleşmesi olan bir şirkette çalışan kişi tarafından yapılıyorsa, iç denetim, yoksa dış denetimdir. İşletmeye yönelik denetimin ilkeleri ve avantajları çalışmada açıklanmıştır. Bu çalışmada denetim sıklığı işletme içi etkileşim ve işletmedeki çalışan sayısının işletmenin iyileştirilmesindeki etkisini incelemek amacıyla bir simülasyon hazırlanmıştır. Hazırlanan simülasyonda işletme içi parametrelere göre ilgili değişimler günlük bazda işlenmiştir. Sonuçta eğer işletme içi tüm parametreler yeterli bir biçimde toparlanırsa denetim sıklığının en fazla 3 ayda bir yapılması durumunda en yüksek iyileşme başarımı elde edildiği görülmüştür. Gelecek dönem çalışmaları, gelişen bilişim teknolojileri yapay zekanın denetçiye denetimler için nasıl kolaylık ve bakış açısı sunduğu konusunda bilgiler sunulmuştur.

Anahtar kelimeler: Denetim, GMP denetimi, Kalite yönetim sistemi, Çevre yönetim sistemi, Uzaktan denetim, Online denetim 


\section{INTRODUCTION}

In today's world, the relationship between the customer and the producer is not only supply and demand, but also the two elements develop each other according to constantly changing needs. For the development of companies and product quality, every step from the source to the final product must be monitored and controlled. These monitoring and inspections can be carried out by machines (Erdoğan, 2019) and/or people. Control by machines is currently only at the data collection level. The main workforce under human control. A Human audit is divided into two types as internal and external. These control types are explained in detail in the second part.

Today, the phenomenon of globalization and the changes in the social sense that are reflected in business life and in the product and consumer-oriented marketing periods of the old days are being replaced by the period of social responsibility. It was during this period that the need for consumer decisions and needs and the interests of the economy and the interests of society emerged. The relationships that companies establish with their social stakeholders are important, and they must take into account both the interests of social stakeholders and their interests. Otherwise, the company's reputation, and thus the desired profit, will decline in the future. All segments of the company, such as employees, shareholders, society, suppliers and customers, can be listed as the company's social stakeholders. The concept of social responsibility is based on the consideration of the interests of these social stakeholders and their interests in the company's decisions. The changing world order has led to a change in the wishes of consumers, employees and all other social stakeholders.

Consumers expect companies to produce high-quality products and show interest in social issues. While carrying out these production activities, customers do not want to pollute the environment. They also want to contribute to the environment (Delmas, 2001), produce recyclable products. We see that consumer demands have changed in Maslow's hierarchy of needs (Kula ve Çakar, 2015). While the society that initially focused on consumption with emotional elements in the early days then took into account the rational elements in consumption, today's consumer is increasingly realizing the consumer activity by attaching importance to spiritual and moral values (Bozkurt, 2013).

Corporate social responsibility in a textile company must first begin at the workplace. Conditions must be created that should be present in the workplace and employees must be valued. Then the company should be aware of its responsibility under market conditions. Responsibility towards consumers should be known and there should be good relations with suppliers. Finally, the company should pay attention to environmental and social issues. The company should minimize damage to the environment and increase its contribution, be committed to human rights and be intertwined with society.

In the literature , it has been observed that it is beneficial to use big data analysis techniques in accounting and financial auditing, in the measurement of financial crises in enterprises, in detecting financial frauds, in stock market predictions, but the use of the technology is a little behind (K1lıç, 2019). In the development of information technologies, it has been observed that software programs and processes that take days can be completed in a much shorter time. Problems with mathematical calculations that require a lot of effort , accumulated paperwork or notebooks could be avoided (Aslan ve K1z11, 2019).

The emergence of COVID-19, in addition to the existing audits that are already required by regulations, laws or urgent needs, and the worldwide travel restrictions, has led to a focus on alternatives that can be used immediately instead of the traditional face-to-face audits. Remote auditing can be a good saving alternative, especially given that most companies limit their travel to business-critical functions and many countries around the world are temporarily closing their borders. Unlike on-site inspections of records, remote audits do not allow simultaneous investigations. During the remote audit, the auditor should take notes and write down questions to be asked during remote interviews. In addition, a video telephone conference call may be organized in which the responsible supervisor and the person responsible for the implementation of the revised program can participate so that questions can be asked simultaneously during the remote review. In this way, documents can be exchanged and reviewed in real-time, and the feasibility of audits should be improved by asking questions and receiving answers at the same time. In the last part of this article, a simulation has been prepared for the audit. For companies, the effects of parameters such as audit frequency, internal communication and the number of personnel in the business have been simulated. The study consists of 9 parts. Introduction in part 1, Audit definition and historical development in part 2 , 
Audit purpose and process in part 3, Principles and characteristics of audit in part 4, Audit types in part 5, Points to be considered by auditors in Covid-19 process in part 6, Audit simulation part 7, Audit simulation results and discussion in part 8 , Conclusion and future work in part 9.

\section{Audit}

The origins of auditing are rooted in history, and when people start living in society, control proves to be an indispensable phenomenon. An audit is an examination of the activities and operations of an organization to determine whether they are in accordance with the objectives and rules set out in advance. It is a process in which findings are made and reports are written as a result of the audit. Audit in general; setting standards to ensure that the results of the activity are as relevant as possible to the plans, comparing the results with these standards and identifying corrective action where practices are separate from the plan (Bozkurt, 2013).

Audit, which is one of management's functions, has important functions for the success of organizations. It follows the planning, organizational, steering and coordination functions of management. Auditing provides an assessment of the results of combining these four functions and reveals new strategies, policies and even a new management philosophy. In this way, it is an important tool that provides feedback on management activity and contributes to the dynamic structure of the existing organizational structure. In this respect, auditing is an activity that is the responsibility of management. Without a functioning audit mechanism, organizations rarely perform their full duties. Therefore, the audit is a must. It comes from necessity.

In order for the audit, which is the responsibility of management to add value to management, it should be expected to operate in accordance with established standards and criteria. The audit is part of the management process. Without the audit, the management process is incomplete. The audit is an important requirement for institutions. If the audit is carried out correctly, it is an important function for institutions, and if it is not carried out correctly, it can cause considerable damage.

Information of the approach of audit, the purpose of the audit and the development of the parties to the audit in history are presented in Table 1 below from the pre-industrial revolution to post 1990.

Table 1

Development of Audit in History

\begin{tabular}{|c|c|c|c|}
\hline Period & Approach Based on Auditing & The Purpose of The Audit & Related Party in Audit \\
\hline Before the industrial revolution & $\begin{array}{c}\text { Auditing of all documents and } \\
\text { records }\end{array}$ & Detecting mistakes and tricks & Operating owners \\
\hline The $1900 \mathrm{~s}$ & $\begin{array}{l}\text { Auditing of all documents and } \\
\text { records }\end{array}$ & Detecting mistakes and tricks & Partners and credit institutions \\
\hline $1900-1930$ & $\begin{array}{l}\text { Auditing of all documents } \\
\text { and records /audit through } \\
\text { samplingenetim }\end{array}$ & $\begin{array}{l}\text { To determine the accuracy of } \\
\text { financial statements }\end{array}$ & $\begin{array}{l}\text { Partners, credit institutions and the } \\
\text { government }\end{array}$ \\
\hline $1930-1960$ & Auditing financial data by sampling & $\begin{array}{l}\text { Providing positive and negative } \\
\text { opinions about the accuracy of } \\
\text { financial statements }\end{array}$ & $\begin{array}{l}\text { Shareholders, credit institutions, } \\
\text { government, unions, consumers and } \\
\text { other related segments }\end{array}$ \\
\hline $1960-1990$ & $\begin{array}{l}\text { Audit through sampling / The } \\
\text { development of statistical sampling }\end{array}$ & $\begin{array}{l}\text { To determine the accuracy of } \\
\text { financial statements }\end{array}$ & $\begin{array}{l}\text { Partners, credit institutions, } \\
\text { government, unions, consumers and } \\
\text { other related segments }\end{array}$ \\
\hline After 1990 & $\begin{array}{l}\text { Risk-oriented audit } \\
\text { Auditing of data processing systems }\end{array}$ & $\begin{array}{l}\text { To determine the accuracy of } \\
\text { financial statements }\end{array}$ & $\begin{array}{l}\text { Partners, credit institutions, } \\
\text { government, unions, consumers and } \\
\text { other related segments }\end{array}$ \\
\hline
\end{tabular}

Reference: (International Standard On Auditıng, adapted from 2009a).

When the above table which presents the development of the audit in history is examined, it is seen that the main purpose of the audit is to reveal errors and tricks based on all documents and records regarding businesses and institutions. Also, in these years auditing activities were made on behalf of business owners, partners and credit institutions. In the period from the 1900 s to the $1930 \mathrm{~s}$, the review of all documents and records was replaced by auditing financial data. In this period as in the previous period, it was aimed to prove the accuracy of the information presented in financial statements and its annexes and importance to create an audit report including the opinions of the auditors in this regard was gained. These audit reports 
created by the auditors provide information for shareholders, credit institutions, government, labour unions, consumers and other interested parties. In the period between 1960-1990 audits provided a sampling of statistically selected noun needed here from all data of businesses and institutions. In the post-1990 period, the adoption of risk-based auditing and information processing systems can be observed. Despite this difference in audit understanding in both periods, in relevant periods the main purpose of the audit is to determine the accuracy of the information presented in the financial statements and its annexes and presentthe results of the audit activity to business-related interest groups.

In addition to this information presented in the table above, Independent Audit Regulation dated 26.12.2012 with Turkey Auditing Standards including information systems auditing, it was decided to comply with international standards in the field of independent auditing (Independent Auditing Regulation, 2012). Therefore, it is possible to say that the importance of information systems auditing has increased in order to determine the accuracy of financial statements in accordance with international auditing standards since 2012, when international auditing principles were adopted in auditing. In addition, the parties in the information age where instant possibility access to today's information includes not only business interest groups but also other users of information outside the country.

\section{Aim of Audit and Audit Process}

It is concluded that the purpose of the audit is necessary to find what is better and more useful than the current situation, to eliminate the differences in implementation, to detect the negative aspects and to make the right decisions (Kebeli, 2012; Bozkurt, 2013).

The objectives of the audit are: to ensure continuity, prevention, and limitation, correction, reforming according to the recommendations made as a result of the audit, to ensure efficiency and effectiveness, to make the various decisions, to seek better and more useful than the current situation within the audited unit, to determine the differences between the application, to take measures and to reveal the negativity in practice (Kebeli, 2012; Bozkurt, 2013). Given the objectives, the purpose of the audit is to provide a generally functional and accountable management approach.

In line with the objectives described above, the process that the inspection should follow can be compared to a building, as shown visually in Figure 1 below. A solid structure must have a solid foundation. Establishing a solid structure in auditing is possible with the determination of audit principles by the audit team on a solid basis. Customer acceptance procedures are like a gate of the building in this structure. At the beginning of the audit process, the enterprise that will be subject to audit first is required to collect the necessary information about the business and assessment of the admissibility of the audit in terms of risk. After that, the customer acceptance process studies are started by signing an audit contract between the parties. In the first stage of the audit process, it is proposed to know the business better by planning. In the following process, evidence collection techniques for business and business operations are applied within the established planning. After the evaluation of collected evidence about the business and completing the identified shortcomings the stage of reporting the results is passed. In the reporting stage, which constitutes the last stage, the auditor's report is prepared based on the evidence found. The audit process in the company ends with the completion of the quality control procedures, which can be likened to the roof of the building (Şavli, 2012). 

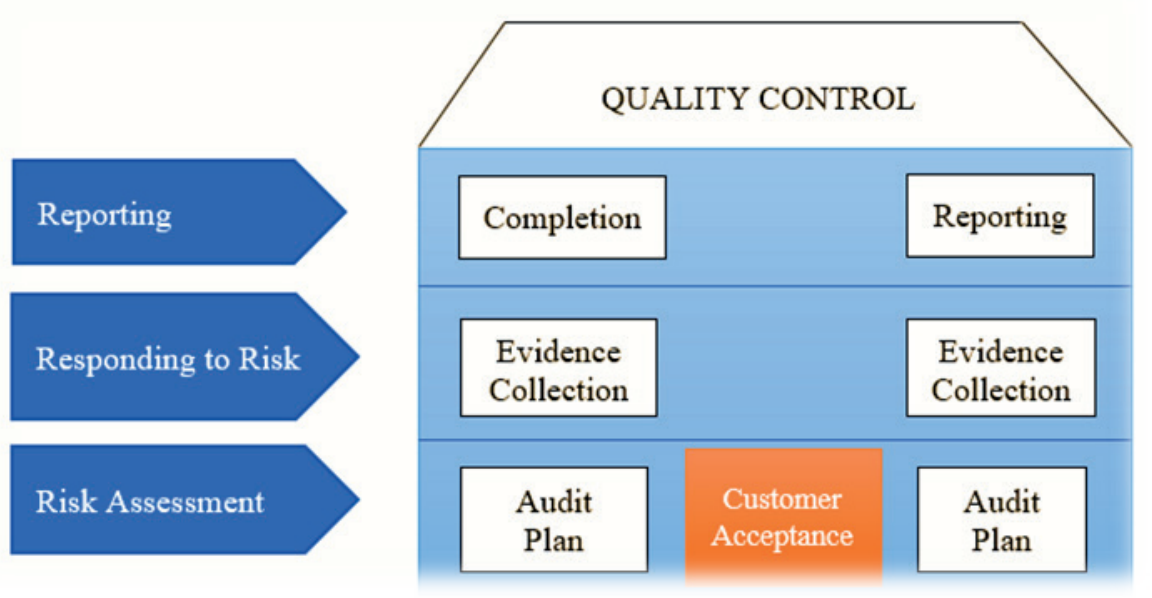

Figure 1. Audit Process (Şavl1, 2012).

\section{Principles and Characteristics of Audit}

In order for the audit to perform the functions expected of it and make a positive contribution to the functioning of the system, the organization and operational view of the audit, which we can express as audit management, should be parallel to the functions to which it is loaded (Kuluçlu, 2006).

In order to achieve the expected benefit, the audit must have the following qualifications:

- The objectives of the audit should be clearly defined,

- There/It Must be a reliable and valid audit system (Akyel ve Köse, 2010).

Audit and audit reports should be appropriate for the period. When planning the audit period, the planning should be such as to ensure that the personnel involved in the audit work to success with maximum efficiency in achieving the audit objectives and targets. The duration of the audit should be kept as short as possible, but it should include sufficient time to achieve the audit objectives. In addition, appropriate time should be scheduled for the audited entities.

Audit reports must be written within a short time after the audit to ensure that the non-conformities identified in the reports are corrected by management and that the proposals are implemented. The audit should be flexible and should not restrict the alternative solutions proposed by management. The audit process and the report produced at the end of the audit should be understandable. If the audited service does not have a good understanding of the audit process, it cannot assist the auditors at the expected level in assessing management risks and the effectiveness of controls to prevent those risks.

The fact that the audit reports are not understandable leads to the risk that the recommendations are not implemented due to management's lack of understanding of the findings and recommendations. The audit should have criteria. The absence of criteria can lead to an inaccurate assessment of risk controls. The audit should be strategic. Instead of focusing on strategic areas, it is a misunderstanding of the audit to remain in arbitrary areas based on random assessments or without criteria. This leads to the idea that the audit is an unnecessary activity rather than the expected benefit. The auditor should be constructive and anticipate corrective action. The audit should not only uncover and criticize nonconformities, but also analyze the causes of errors and provide proactive solutions to prevent recurrence.

With the audit;

- It is used to determine the degree of success of organizations in system applications. 
- It ensures that non-conformities cannot be detected by the organization itself.

- Corrective and preventive activities of the organization should be strengthened and maintained more effectively.

- The status of the process is analyzed and the points to be optimized are determined.

- Process and organizational improvements are provided with the provided improvement suggestions.

- As a result of all improvement activities, the efficiency of the organization is increased, costs are reduced, alternative costs are determined, and better products/services start to be offered.

- As a result of all these improvements, the organization gains prestige and trust in the market.

\section{Audit Types}

The types of audits can be classified according to various criteria. Within the study, audits are divided into two parts. These are internal audits and external audits.

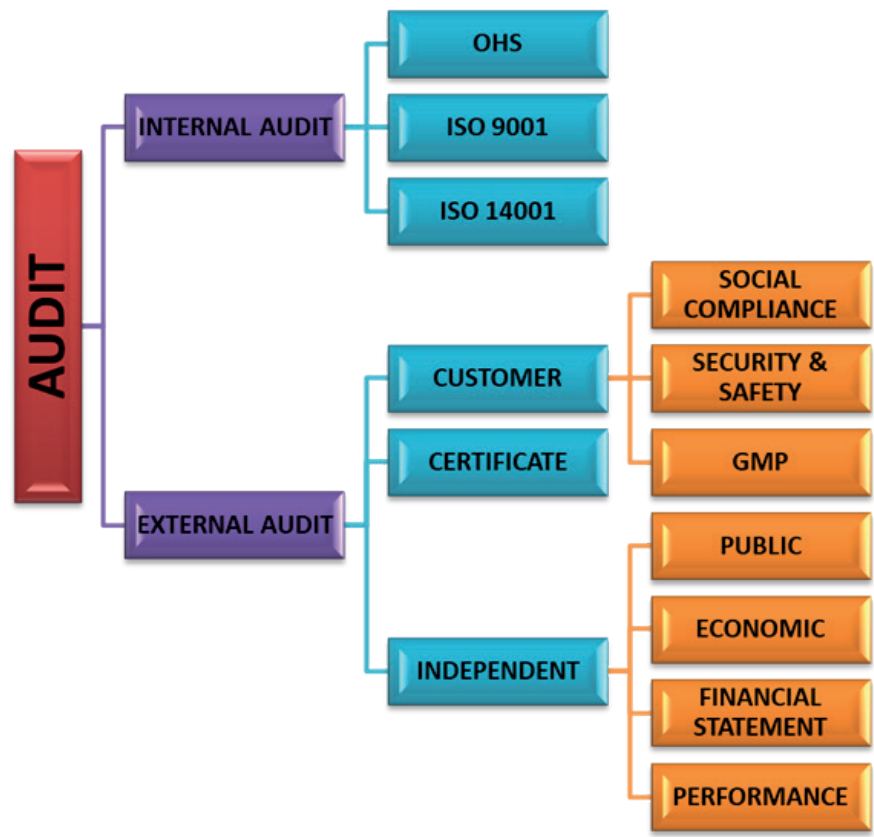

Figure 2. Audit types

\subsection{Internal Audit}

Internal audit is the examination of all business activities which are in the permanent status of the company or which offer a continuous status as internal auditor from outside the company. In other words, it is a type of audit carried out by the people who work in a company with a wage contract. Internal auditors are those who work within the organizational structure of the company and generally present the information they receive to the management of the company. The main tasks of internal auditors are to monitor the internal control structure of the institutions and organizations to which they are affiliated and to make proposals. The internal audit is an important tool for companies to examine the effectiveness of their activities and to show the extent to which the entity has achieved its objective. Internal auditors carry out their activities within the scope of their responsibilities as defined by them under the Board of Directors. In addition to this information about internal audit and internal auditors, it can be said that the number of internal auditors is also important to ensuring its effectiveness in the internal audit. However, when table 2, in which the number of cadres allocated for internal auditing in public administrations was presented in our country in 2018, is examined, although the number of staff assigned to internal auditors is 2.054 , only 880 of this number are employed and the other 1,174 staff are not employed. Therefore, the occupancy rate of internal auditors is only 43.03 percent. This rate in the number of internal auditors employed also negatively affects the effectiveness of internal audit in our country ( Ministry of Treasury and Finance, 2021). 
Table 2

Internal Auditor Staff in Republic Administration

\begin{tabular}{ccc}
\hline Total Cadre & Full Cadre & Empty Cadre \\
\hline 2.054 & 880 & 1.174 \\
\hline
\end{tabular}

Reference: (Ministry of Treasury and Finance, Number of Full-Empty Internal Auditors Cadre, 2021).

The duties of the internal auditor are listed as follows (Regulation on Working Procedures and Principles of Internal Auditors);

- "To evaluate the management and control structures of public administrations on the basis of an objective risk analysis.

- To conduct investigations and make recommendations with a view to effective, economical and efficient use of resources.

- To verify compliance with laws by expenditure.

- To monitor and evaluate the consistency of the administration's expenditure, decisions and savings on financial transactions with the objectives and policies, development plan, programs, strategic plans and performance programs.

- To audit the system of financial management and control processes and make suggestions on these matters.

- To make suggestions for improvement in the context of the audit results and follow up on them.

- To inform the highest superior of the respective administration if during the audit or after the audit a situation arises that requires investigation.

- To verify the accuracy of the information produced by the public administration.

- Assist in establishing performance indicators when deemed necessary by the most senior manager and evaluate the applicability of the established performance indicators.

- To inform the most senior manager of the findings of criminal situations “.

\subsubsection{ISO 9001 Internal Audit}

Considering the fact that consumers have quality, that their expectations of goods and services are increasing, and that they are difficult and not easy to meet, it can be said that quality plays a strategic role in achieving competitive advantage. In this respect it is a well-known fact that quality is one of the sines qua non of companies today. The literature shows that internal audits contribute to the revitalization of corporate performance (Alič ve Rusjan, 2010).

ISO 9001 Quality management System The aim is to record every process of the organizations published by the World Standards Organization in the production or service sector and to ensure customer satisfaction at all levels of management on the basis of continuous improvement. ISO 9001 internal audits are reviewed and reinforced by an internal auditor who has ISO 9001 basic training and a certificate as an internal auditor and knows whether or not he meets the requirements of the quality management systems of companies. They prepare and implement the studies that prove the existence of the substances of ISO 9001 standard in the company.

\subsubsection{ISO 14001 Internal Audit}

ISO 14001 Environmental Management System is the management system standard published by the international standards organization which identifies and describes the studies to be done to minimize the damages to the environment as a result of the interaction of the enterprises with the environment during their processes (Jiang ve Bansal, 2003). Because ISO 14001 Environmental Management System is a management system standard, a company can be established and applied alone, and because it has common clauses with ISO 9001 Quality Management System standard, it can be installed and implemented in integration with management system standards such as iso 9001 standard and OHSAS 18001 standard. Businesses that establish and implement the ISO 14001 Environmental Management System should certify this standard with ISO 14001 certification. ISO 14001 internal audits are checked and reinforced by an internal auditor who has received ISO 14001 basic 
training and internal auditor certificate and checks whether or not the company meets the quality management system rules. ISO 14001 standard in the enterprise shows that the existence of substances in the establishment of the documentation set up and implement the application.

\subsubsection{OHSAS 18001 Internal Audit}

OHSAS 18001 is an international standard that determines the requirements for the occupational health and safety management system (Fernández-Muñiz, Montes-Peón ve Vázquez-Ordás, 2012). OHSAS 18001 has been developed in compliance with ISO 9001 (QMS) and ISO 14001 (EMS) standards to enable organizations to integrate quality, environmental and occupational health and safety management systems. Compliance with national health and safety standards is mandatory for all organizations. Occupational Health and Safety Management System is a systematic and scientific way of identifying hazards and risks and taking precautions against these hazards and risks to protect them from accidents and other effects that may cause health damage due to various reasons and to provide a better working environment during the realization of work at workplaces. The company is constantly monitored by the occupational safety advisor in terms of occupational safety who reports to senior management.

\subsection{External Audit}

This is an audit conducted by audit staff and institutions, which are not related to the functional and organizational hierarchy of the audited company and which is independent of it, to express opinions on the legality, regularity of the operations of the related company and efficiency, frugality and efficiency of management. The external audit may be the customer audit with the customer request, International Organization for Standardization (ISO) 9001 and 14001 and others certificate audits and public audits.

\subsubsection{Customer Audit}

Customer audit activities, which are performed by an auditor on behalf of the audit firm whether or not for certification purposes, at the request of customers. The audit is carried out by an impartial audit company to determine the system implementation level of the organization, nonconformities, the effectiveness of corrective and preventive activities, the status of its processes, and the points that need to be improved. In particular, audits made by customers of a third party; Social compliance audits, security and safety audits, and Good manufacturing process (GMP) audits.

A social compliance audit is carried out under the name of social responsibility audit or social compliance audit to determine and improve the working conditions of the manufacturers in the supply chains of big brands. The globalizing world and rising consumer awareness are based on the determination and evaluation of large companies' suppliers. International Labor Organization, local and national units are published in the official newspaper. Laws, regulations, the rules and regulations specified in the regulation are based on scoring the degree of compliance. Local statutory requirements are audits that are assessed and reported in line with customer expectations. The Code of Ethics includes controls to ensure assurance to entities requesting audit and having commercial relations with the audited entity.

In social compliance audits, the auditor checks the code of conduct of the company. These are;

- Forced labor,

- Payments,

- Working hours,

- Child labor,

- Discrimination,

- Employee Awareness,

- Prevention of Harassment and Abuse 
- Rest Days and Holidays

- Labor Discipline

Occupational Health and Safety: It considers human beings as the most valuable asset in all branches of activity and considers it a primary goal to minimize any loss of life and property by providing a healthier and safer work environment. It organizes pieces of training to ensure that all employees are aware of their responsibilities and provides the necessary personal protective equipment for occupational health and safety. Occupational Health and Safety aim to comply with local laws and regulations within the scope of which all personnel can work under the Occupational Health and Safety policy. Occupational health and safety risks, environmental measurements, periodic checks, electrical internal installation compliance reports, and electrical ground measurement and controls should be identified. It aims to keep these risks under control by reducing them to acceptable levels.

An evaluation score is given to the company after the record controls. After the audit, the company is given a CAPA (Corrective and Preventive) report in which nonconformities are written. The audited company sends a report to the impartial audit firm with a description of the dates and activities for these nonconformities. Finally, the report is presented to the customer by the audit firm.

GMP is a quality system that guides the manufacturers in terms of the conditions under which GMP standards should be produced in many sectors with good manufacturing practices. The use of the GMP standard is used in particular in the United States as cGMP. The letter "c" used at the beginning of the GMP standard stands for "Current", meaning "dynamic. The GMP standard is not a one-off system. It is a production technique that is continuously controlled and kept under control, correcting the systemic or operational deficiencies that arise during these controls and developing based on the innovations brought by today's technology and sectoral studies. Topics covered in the GMP audit are Management commitment and continual improvement, Risk management, Quality management, Site and facilities management, Product control, and Personnel training. (Figure 3.)

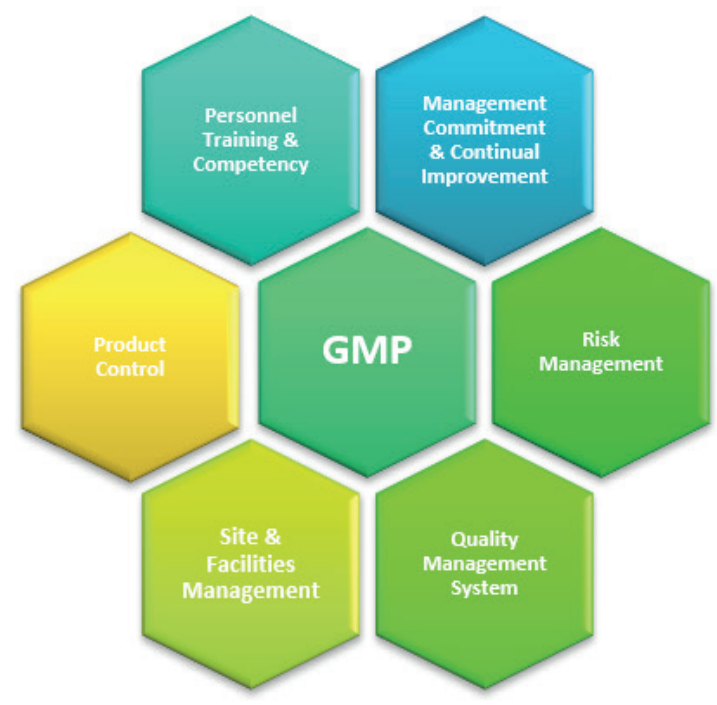

Figure 3. Topics examined in GMP audit

Particular points a GMP auditor pays attention to; how and where the records are kept, training procedure, whether adequate training is provided, and the calibration of test devices.

\subsubsection{Certification Audit}

Certification audit is the process of issuing the certificate which is valid for 3 years as a result of the certificate renewal audit after the expiry of the ISO 9001 and 14001 certificates issued for 3 years, provided that the enterprises carry out an audit 
every year in accordance with the accreditation rules. Obtaining an ISO certificate is not a document nor is it sold on the shelf. First of all, a company should establish the documentation showing the existence of the certificate standard in its business as ISO 9001,14001. Upon this, the company must determine an accredited organization and apply for ISO 9001 Certification and remove any major or minor errors in the system that occur as a result of this certification audit and as a result, obtain ISO Certificate from the ISO Management system certification.

\subsection{Independent Audit}

An independent audit is an audit performed by independent auditors who are not affiliated with the institution it audits. The concept of independent audit has been included in Law No. 6102 which entered into force on 01.07.2012 for the first time in our commercial law. Independent audit means the audit and evaluation of the financial statements and other financial information following the financial reporting standards by applying the required independent audit techniques to obtain sufficient and appropriate independent audit evidence, to provide reasonable assurance and to be evaluated and linked to the report. Thus, a complete standard will be provided in the financial statements of the companies and the comprehensibility of the financial statements will be increased. An independent audit is carried out by external auditors who are not loyal to the institution they audit.

The following are the basic characteristics that the independent auditor should have (Cömert ve Uzun, 2014);

- Impartiality, honesty and authority to the extent that the duty requires,

- Work independently and have reporting responsibilities,

- Evaluate internal controls, risk management processes, and corporate governance processes as they relate to the company, and perform the audit of the financial statements,

- Comply with the requirements of laws and standards,

- Protect the interests of all stakeholders and interest groups associated with the Company,

- Serve the public interest (Cömert ve Uzun, 2014).

\subsubsection{Public audit}

These are the audits carried out by the inspectors of public institutions to ensure public order and protection of public rights. Public audits are carried out by auditors affiliated to the ministry and other public organizations based on the provisions of the law (Korkmaz, 2007). Some ombudsmen performing ombudsman activities can be listed as follows (Independent audit under international audit standards, 2009b).

- Ministry of Finance auditors,

- Ministry of Finance account experts,

- Capital Markets Board (CMB) auditors,

- Banking Regulation and Supervision Agency (BRSA) auditors,

- Social Security Institution (SGK) inspectors.

\subsubsection{Economical audit}

Financial statements are a type of audit in which compliance and performance audits are conducted and reported together. Within the scope of the economic audit; on the one hand, it is determined whether the activities of the organization are carried out under the legislation in force, and on the other hand, the compliance of the financial statements with the current financial legislation and generally accepted accounting standards are made through a detailed examination, taking into consideration all operational functions of the resources allocated to the organization, efficiency, and is used following the principles of frustration measures and makes recommendations in this direction. 


\subsubsection{Financial Statements audit}

The department that is directly related to the activities and results of an enterprise is not only the owner or partners of that enterprise. The source of information about the activities and results of the enterprises are the accounting records and documents of that enterprise and the financial statements prepared based on these enterprises. The purpose of the audit of financial statements is to determine the irregularities that would prevent the realization of the objectives expected in these statements or in other words, to determine the reliability of these statements by measuring the degree of compliance with the principles, accounting procedures and principles, laws and all other predetermined criteria (Dalak, 2000). This audit is performed by independent auditors and ombudsmen. In this context, the general elements of the financial statements audit are presented in Table 2 below.

Table 2

Elements of the Financial Statement Audit

Aim Examination of the accuracy and reliability of the information presented in the financial statements

Content financial statements and annexes

Criterion Generally accepted accounting principles and other regulations affecting financial information

Reference: (Independent Audit Under International Audit Standards, 2009b).

\subsubsection{Performance audit}

This audit comprehends all levels of management in terms of their frugality, efficiency, and effectiveness in their programming, implementation, and monitoring stages. It covers the review of the implementation of procedures and methods associated with these activities to assess the efficiency and effectiveness of an organization's activities (Kubali, 1999 ; Öztürk, 2014).

The following are the purposes of performance auditing:

Kubali et.al explained that the primary purpose of performance auditing is to provide the state with information on the use of resources and to make recommendations to managers by providing impartial and independent information. The second purpose of performance auditing is to encourage the audited entity to take the necessary steps to improve its systems and controls to achieve maximum efficiency with the resources spent. The main objectives of performance auditing announced at the 12th Congress of SAI (Supreme Audit Institutions) in Sydney in April 1986 are as follows;

- Improving public administration,

- Providing reliable information to the legislature and the public on the results of the administration's work,

- Encouraging the administration to evaluate its own performance,

- Ensuring that the chain of accountability is extended (Kubali, 1999).

\section{Points to Be Consider By Auditors in the Covid -19 Period}

During the Covid 19 pandemic, auditors need to access more information and documents about the company and its environment to assess the impact of the 2020 financial statements on the economy. In this context, the following are the items that auditors should focus more on during the Covid-19 process (Demir, 2020).

\subsection{Risk Assessment and the determination of Material Misstatement Risks by knowing the company and its environment "ISA 315 regarding the determinations to be given to the Assessed Risks and the valuation"}

The Independent Auditing Standard (ISA) 315 governs the auditor's responsibility to identify and evaluate the risks of material misstatement in the financial statements in order to familiarize the auditor with the entity and its environment, including the entity's internal control (Independent Auditing Standard-315).

As part of this auditing standard, the auditor should assess how financial and operational actions should be taken as a result of epidemics such as Covid-19. In this context, the auditor should also evaluate a possible disruption in the companies' relationships with customers and suppliers and the risks that may be caused by a disruption (Türmob, 2020b). 


\section{2. "ISA 500 Independent Audit Evidence" at Independent Audit Evidence}

In disclosing audit evidence, ISA 500 addresses the auditor's responsibility to plan and perform audit procedures to reach appropriate conclusions. This auditing standard is also applicable to any audit evidence obtained during the audit (Independent Auditing Standard-500).

During the Covid 19 epidemic process, constraints such as curfew and transportation should be considered by the auditor, and in this direction, data sharing should be enabled by organizing meetings in a digital environment (Türmob, 2020b).

\subsection{Regarding independent audit evidence, "ISA 540 Independent Audit of Accounting Estimates and relevant disclosures, including those with fair value"}

ISA 540 sets out the auditor's responsibilities in relation to estimates and disclosures in the audit of financial statements. In addition, there are provisions and explanations within this standard for assessing misstatements of accounting estimates and indicators of potential management bias (Independent Auditing Standard-540).

Since the Covid 19 epidemic process creates a great predictive difficulty worldwide, it is of great importance that the auditor uses his professional judgement during the epidemic process by reviewing all accounting estimates of the company (Türmob, 2020a).

\subsection{Regarding the Use of Third Party Work " 570 Business Continuity"}

ISA 570 sets out the auditor's responsibilities in relation to the continuity of the entity and the impact of going concern on the auditor's report (Independent Auditing Standard-570). In this context, the financial statements are prepared on a going concern basis. Therefore, unless the manager intends to cease the economic activity of the entity, the manager is responsible for acting on the going concern basis. However, financial statements prepared for specific purposes may or may not be prepared on a going concern basis of accounting. Where it is appropriate to apply the going concern principle, assets and liabilities are arranged on the basis that the entity will meet its assets and liabilities from which it will benefit (Independent Auditing Standard-570).

It is understood that Covid-19 may have a significant destructive impact on the financial structures of companies. Therefore, companies may have difficulty meeting their debt obligations. At this point, management should classify short-term and long-term financial liabilities and determine which liabilities have been affected by the epidemic process and how this effect affects the continuity of the company (PWC, 2019). However, the impact of sudden fluctuations in exchange rates during the epidemic process on the financial statements and business continuity should be evaluated. If the auditor finds any uncertainty about the continuity of the business during this process, he should not refrain from issuing a qualified opinion (Türmob, 2020a).

\subsection{Findings of Independent Audit and Reporting "Responsibilities of 720 Auditors in Relation to Other Information."}

ISA 720 addresses auditor's responsibilities in relation to information other than the auditor's opinion included in an entity's annual report. In this context, companies' annual activity reports may consist of a single document or a combination of several documents that serve the same purpose (Independent Auditing Standard-720).Under this auditing standard, a material misstatement of financial statements is considered to exist when other information is materially inconsistent with the financial statements or with information obtained by the auditor during the audit process. Therefore, in such cases, when the reliability of the auditor's opinion could be affected, the auditor is required to consider other information Independent Auditing Standard-720). During the Covid-19 outbreak, the auditor should also assess whether the information in the annual report prepared by management is consistent with the data presented in the companies' financial statements, whether the annual report provides explanatory information to the parties that require it, and whether the relevant report fully presents the objectives and risks of the company's future (Türmob, 2020a). 


\section{Audit Simulation}

Process changes in industrial facilities will cause both time and cost. These processes are first tested with simulations or small-scale applications. In this part of the paper, the effect of the number of employees in a company, the frequency of audit, the rate of interaction between employees on the company's recovery time, the number of employees fired and the number of employees recovered is examined. The simulation is prepared in Python programming language with the simpy library (Matloff, 2008). The simulation works on a daily basis. Audit frequency is the period of audit of the company by internal or external auditors. These parameter values were chosen as 4, 8, 13, 26 and 52 weeks. The number of employees working in the company was chosen as 50 and 100. Interaction between employees refers to how much continuous employees in the company interact with each other on a daily basis. This value states that when employees don't conform , others see and are affected by this nonconformity and spread the nonconformity. The spread of nonconformity is defined as a random process and the probability of spreading nonconformity when two employees interact is assumed to be $50 \%$ in the simulation. In the simulation, each employee is run as one thread. The probability of self-nonconformity of employees was set as $10 \%$. Nonconformist employees are detected and warned by the person responsible for the audit . The probability of an unsuitable worker overlooked from the audit was set to $10 \%$. The probability of recovery for the warned employees was assumed to be 0.8 . If the employee has not recovered after 2 inspections, they will be fired. Some screenshots taken during the simulation are presented in Figure-4.

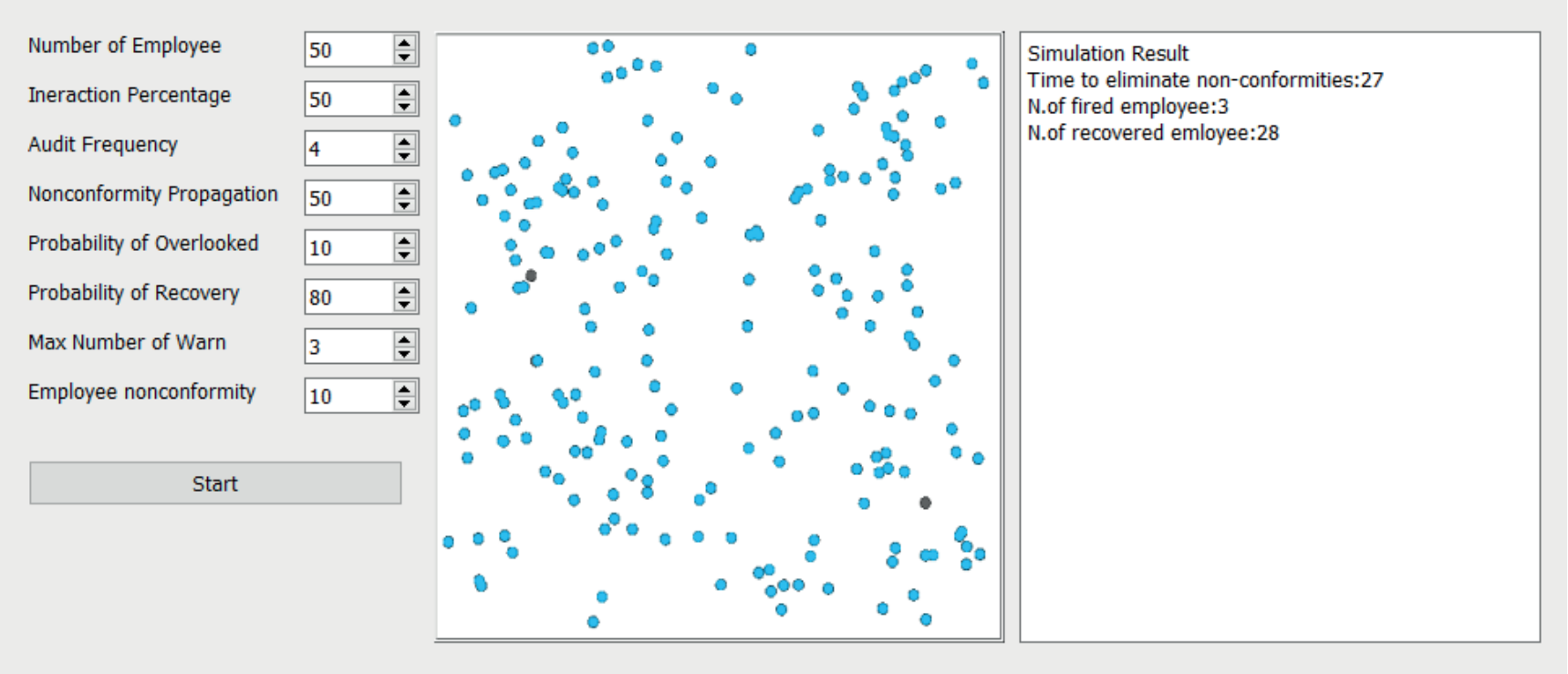

Figure 4. Audit Simulation User Interface

\section{Audit Simulation Results and Discussion}

The first parameter examined was the duration of elimination of nonconformities in the firm by changing the audit frequency in the simulation. The second parameter studied in the simulation was the impact of audit frequency on the employees in the company. The number of employees who did not cover their compliance was determined by changing the audit frequency. Finally, the simulation changed the interactions of the employees in the company and examined the effect of non-conformities on closing time. The number of employees recovering is shown in Figure 5. Changing the frequency of the audit or changing the interaction during the simulation generally did not significantly change the number of employees who recover. It can be seen that the standard deviation is only larger when the audits are tightened. 


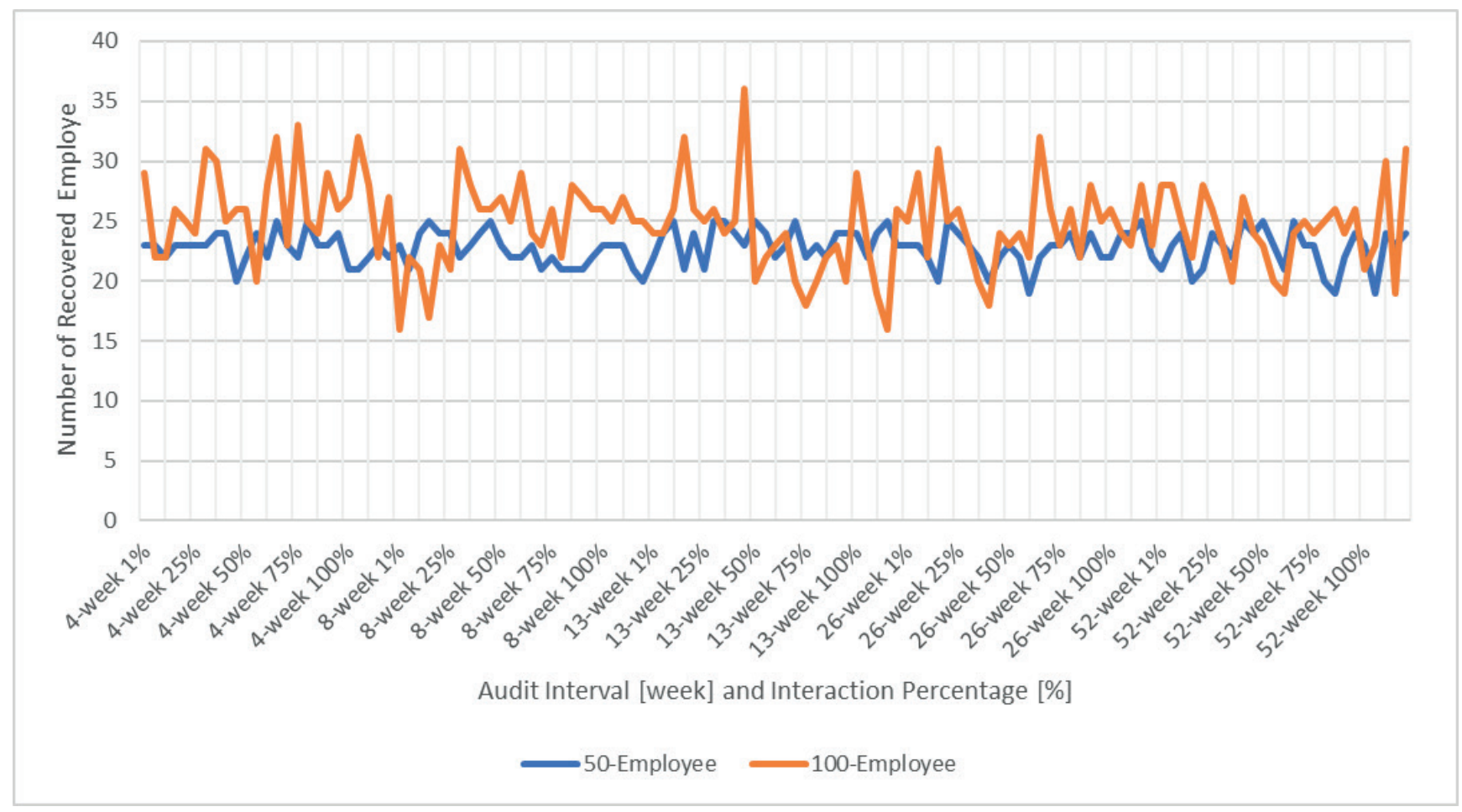

Figure 5. Audit Simulation on Number of Recovered Employee

Figure 6 shows the change in the number of fired employees. Increasing the frequency of audit or increasing the interaction does not lead to a significant change in the number of fired employees . It can only be said that as the number of employees increases, the number of firings also increases.

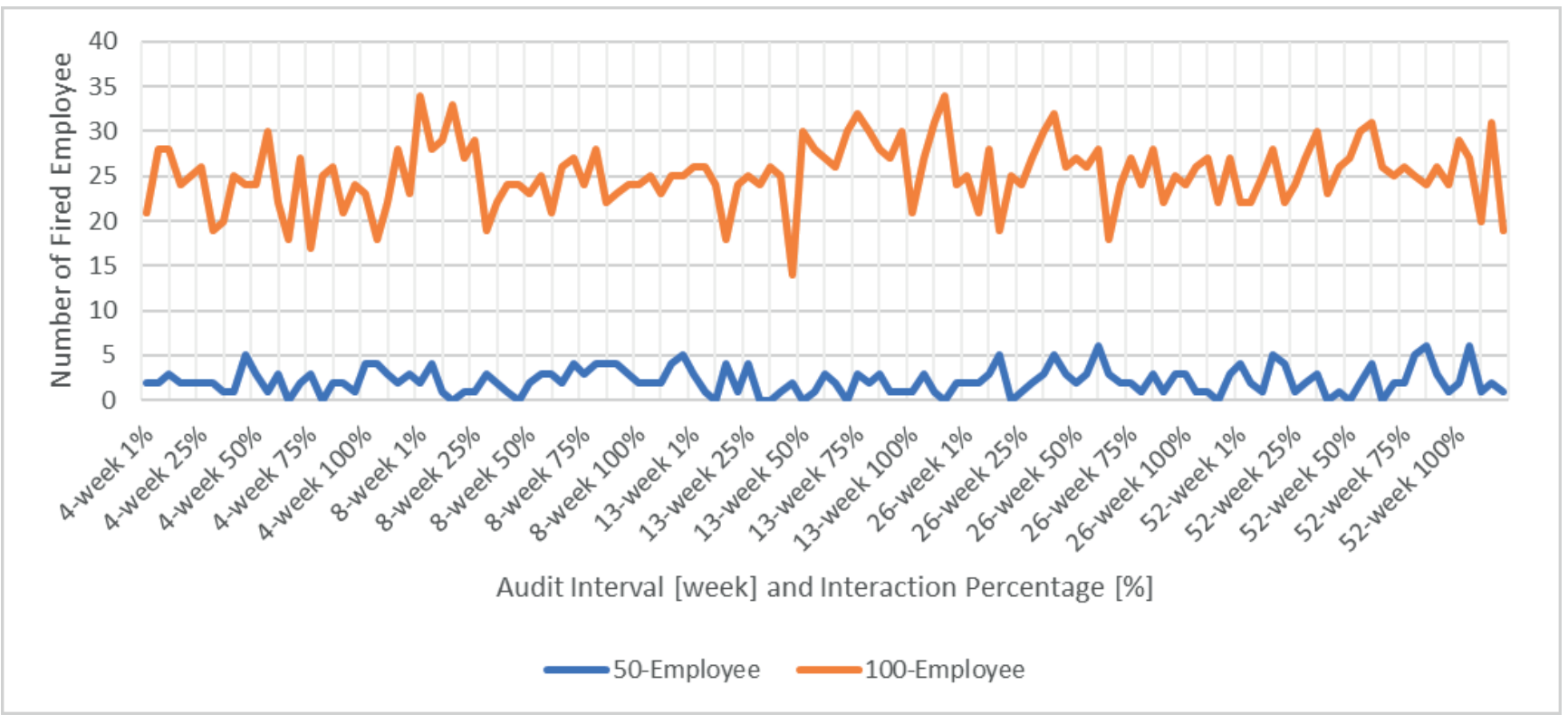

Figure 6. Audit Simulation on Number of Fired Employee

Figure 7 shows the recovery times of the company. As can be seen, recovery from nonconformities is delayed as interaction within the company increases. The company's recovery time suggests that the interaction should be lower and the frequency of audits higher. In 13-week audits in companies with fewer employees, it was observed that even with $75 \%$ interaction, the nonconformities in the company can be eliminated. However, irrespective of the number of employees, similar behavior is 
observed when audits are conducted semi-annually or once a year. The graph shows that if audits are conducted at least every 3 months, success can be achieved even in companies with high employee interaction.

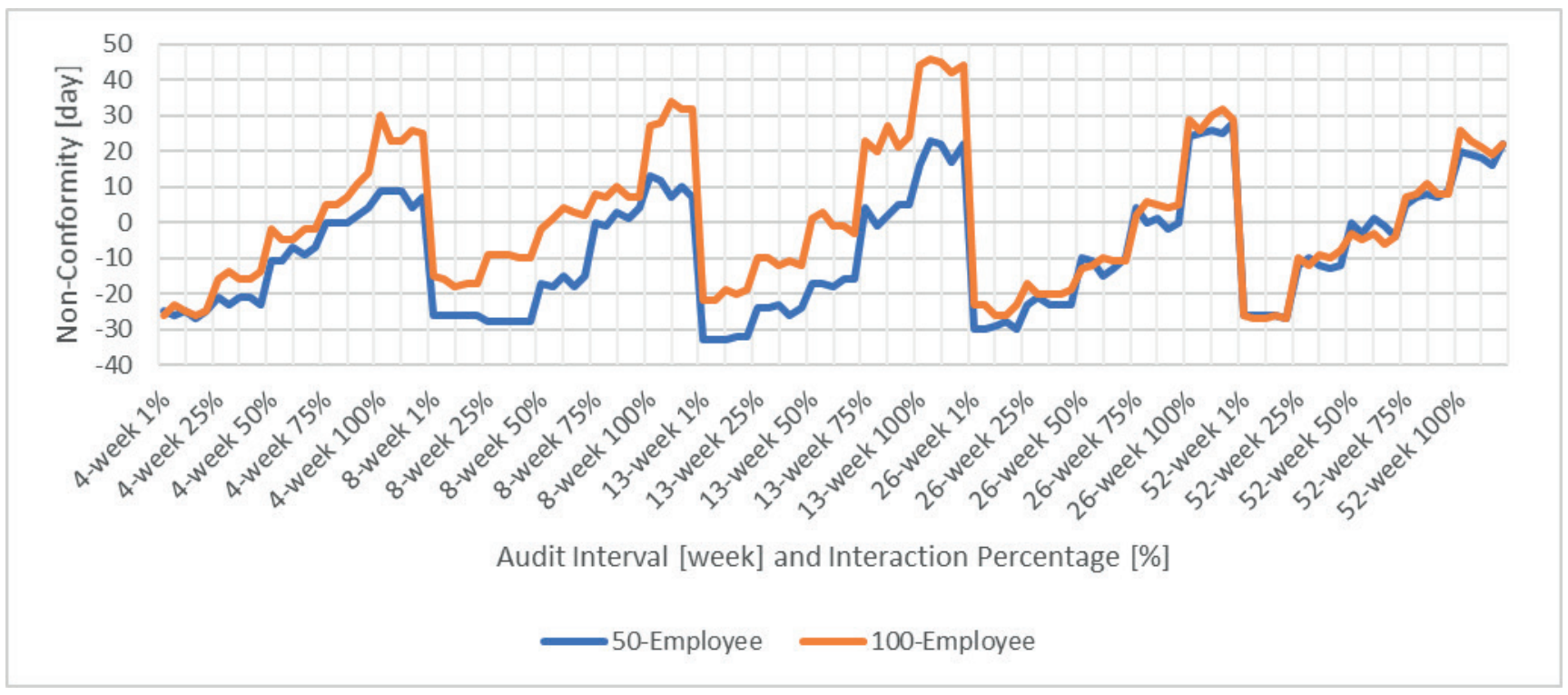

Figure 7. Audit Simulation on Elimination of Non-conformity

\section{Conclusion and Future Works}

Textile companies need to develop competitive strategies and flexibly adapt these strategies in line with today's conditions to survive in today's competitive and volatile world. The concept of the audit is evolving in many countries and the focus of the audit approach is changing. The audit approach in Turkey is following a parallel course with global developments. The importance and benefits of auditing in a textile company are becoming more and more noticeable. The audit, which may be encountered in different ways in terms of its name, structure, and location, has an important function to achieve the goals and objectives determined by the management. Changes in the audit approach to better fulfill this function are closely followed in many countries and Turkey. In this study, a simulation was prepared to investigate the effect of audit frequency, internal interaction and number of employees in the company on the improvement of the company. In the prepared simulation, relevant changes were processed according to internal parameters on a daily basis. As a result, it was found that with sufficient recovery of all parameters within the company, the highest improvement success is achieved when the audit frequency is conducted at least every 3 months.

In a textile company, data storage and processing are carried out through computers by greatly reducing the labor force benefiting from automation and digitalization. With technological advances, it is tried to facilitate information control at the optimum level in the companies. Various artificial intelligence applications are available in textile enterprises (Shamey ve Hussain, 2003; Karthikeyan ve Sztandera, 2010; Seçkin, Seçkin ve Coşkun, 2019). Data processing in the computer environment has given the information using a great opportunity to diversify the information. In this case, the data traffic is more diversified and concentrated. The audit of this big data is becoming more difficult than before. At this point, the auditor focuses more on analytical audit methods than before. As an auditor, if we look at the process of digitization and automation from another perspective, this can be a great advantage for an auditor. Since the records and documents are in the digital environment and the algorithms are on the system, an audit can be performed with the support of artificial intelligence and can increase the level of assurance (Mert ve Tas, 2019). Cognitive technologies can be considered to reduce or possibly eliminate the need for auditors. Cognitive technologies have indeed enabled the automation of manual tasks such as stock counting or drafting communications for decades. However, this will allow the auditor to focus more on focusing on risky areas than on habitually focused areas. However, cognitive technologies can not only automate routine tasks but can also enhance the professional judgment of the auditor by modeling thought processes that can be compared to the initial results. 
With the developing information technologies, recently especially due to COVID 19, remote auditing can be a good saving alternative, especially given that most companies limit their travel to business-critical functions and many countries around the world are temporarily closing their borders. A video-telephone conference call may be organized in which the responsible supervisor and the person responsible for the implementation of the revised program can participate, so that questions can be asked simultaneously during the remote review. In this way, documents can be exchanged and reviewed in real time, and the feasibility of audits should be improved by asking questions and receiving answers at the same time.

Peer-review: Externally peer-reviewed.

Conflict of Interest: The authors have no conflict of interest to declare.

Grant Support: The authors declared that this study has received no financial support.

Author Contributions: Conception/Design of Study- M.S., F.K., A.Ç.S.; Data Acquisition- M.S., F.K., A.Ç.S.; Data Analysis/Interpretation- M.S., F.K., A.Ç.S.; Drafting Manuscript- M.S., F.K., A.Ç.S.; Critical Revision of Manuscript- M.S., F.K., A.Ç.S.;Final Approval and Accountability- M.S., F.K., A.Ç.S.

Hakem Değerlendirmesi: Dış bağımsız.

Çıkar Çatışması: Yazarlar çıkar çatışması bildirmemiștir.

Finansal Destek: Yazarlar bu çalışma için finansal destek almadığını beyan etmiştir.

Yazar Katkıları: Çalışma Konsepti/Tasarım- M.S., F.K., A.Ç.S.; Veri Toplama-M.S., F.K., A.Ç.S.; Veri Analizi/Yorumlama-M.S., F.K., A.Ç.S.; Yazı Taslağı- M.S., F.K., A.Ç.S.; İçeriğin Eleştirel İncelemesi-M.S., F.K., A.Ç.S.; Son Onay ve Sorumluluk- M.S., F.K., A.Ç.S

\section{References/Kaynaklar}

Akyel, R. ve Köse, H. Ö. (2010). Kamu Yönetiminde Etkinlik Arayişi: Etkin Kamu Yönetimi İçin Etkin Denetimin Gerekliliği [Search for Event in Public Administration: for Effective Public Administration The Requirement of Effective Audit]. Türk İdare Dergisi, (466), 9-45.

Alič, M. ve Rusjan, B. (2010). Contribution of the ISO 9001 internal audit to business performance. International Journal of Quality \& Reliability Management, 27(8), 916-937.

Aslan, T. \& Kız1l, C., (2019). İktisadi ve Sosyal Yönleriyle İnovasyon, İKSAD Publishing House. Chapter 5 İnovasyonun Muhasebe ve Denetime Etkileri”. s. $159-196$.

Bozkurt, P. (2013). Denetim Kavrami ve Denetim Anlayişindaki Gelişmeler [Audit Concept and Supervision Understanding Improvements]. Denetişim, (12), 56-62.

Cömert, N. ve Uzun, A. K., (2014). Bağımsız Denetçiler İçin İtibar Yönetimi [The Significance of Advertisement on The Reputation Concept and Advertisement Influence on Branding World]. İstanbul Aydın Üniversitesi Dergisi, 9(2), 1-23.

Dalak, G. (2000). Denetim ve kalite denetimi. Muğla Üniversitesi Sosyal Bilimler Enstitüsü Dergisi, (1), 65-79.

Delmas, M. (2001). Stakeholders and competitive advantage: The case of ISO 14001. Production and Operations Management, 10(3), 343-358.

Demir, Z. (2020). Covid-19'un TFRS Kapsamindaki Finansal Raporlamaya Olan Etkileri ve TMS Kapsaminda Denetçinin Dikkate Almasi Gereken Hususlarin Değerlendirilmesi [Evaluation of The Effects of Covid-19 on Financial Reporting Under The Scope of TFRS and The Issues That Must be Considered By The Auditor in The Scope of TMS]. Journal of Acounting and Auditing Overview, 21(61), $255-278$.

Erdoğan, M. (2019). Denetim 4.0 ve Ötesi. [Audit 4.0 and Beyond]. Muhasebe ve Vergi Uygulamalari Dergisi (MUVU)/Journal of Accounting \& Taxation Studies (JATS), 12(3).

Fernández-Muñiz, B., Montes-Peón, J. M. ve Vázquez-Ordás, C. J. (2012). Safety climate in OHSAS 18001-certified organisations: Antecedents and consequences of safety behaviour. Accident Analysis \& Prevention, 45, 745-758.

Jiang, R. J. ve Bansal, P. (2003). Seeing the need for ISO 14001. Journal of Management Studies, 40(4), $1047-1067$.

Karthikeyan, B. ve Sztandera, L. M. (2010). Analysis of tactile perceptions of textile materials using artificial intelligence techniques: Part 1: forward engineering. International Journal of Clothing Science and Technology, 22(2/3), 187-201.

Kebeli, A. (2012). Kamu Iç Denetiminde Kurumsal Performans Denetimi. [The Place of Performance Auditing in The Public Internal Auditing], Journal of Denetim, (20), 5-34.

KGK Independent Auditing Standard-315, (2020, 1 January). “ Identifying and Assessing Material Misstatements by Knowing the Business and its Environment”. Retrieved from https://kgk.gov.tr/Portalv2Uploads/files/Duyurular/v2/BDS/bdsyeni25.12.2017/BDS\%20315-Site.pdf

KGK Independent Auditing Standard-570, (2020, 28 December). “Business Continuity”, Retrieved from https://www.kgk.gov.tr/Portalv2Uploads/files/ Duyurular/v2/BDS/BDS\%20570.pdf

KGK (Public Oversight Authority), (2020, 28 December). Independent Auditing Evidence-720, “ Responsibilities of the Independent Auditor Regarding Other Information”. Retrieved from https://kgk.gov.tr/Portalv2Uploads/files/Duyurular/v2/BDS/BDS\%20720.pdf

KGK Independent Auditing Standard -500, (2020, 26 December). "Independent Auditing Evidence”. Retrieved from https://www.kgk.gov.tr/Portalv2Uploads/ files/Duyurular/v2/BDS/BDS_500_kurumsitesi.pdf

Kiliç, Ö. Ü. B. İ. (2019). Big Data Analysis Techniques and Technologies in The Field of Accounting, Finance and Auditing International Congress of Management Economy and Policy-ICOMEP'2019 Autumn, Proceedings Book, p. 498 https://www.researchgate.net/profile/Oezlem-Erguet/ publication/338922004_ICOMEP\%2719_AUTUMN_PROCEEDINGS_BOOK/links/5e3300db299bf1cdb9ff2471/ICOMEP19-AUTUMNPROCEEDINGS-BOOK.pdf\#page $=508$ 
Korkmaz, U. (2007). Kamuda Iç Denetim [İnternal Audit in The Public]. Bütçe Dünyası Dergisi, 2(25), 4-15.

Kubali, D. (1999). Performans denetimi [Performance Audit]. Amme İdaresi Dergisi, 32(1), 31-62.

Kula, S. ve Çakar, B. (2015). "Maslow Ihtiyaçlar Hiyerarşisi Bağlamında Toplumda Bireylerin Güvenlik Algııı ve Yaşam Doyumu Arasındaki Ilişki”" Bartın Üniversitesi İBF Dergisi, 6(12), 191-210.

Matloff, N. (2008)." Introduction to discrete-event simulation and the simpy language. Davis, CA. Dept of Computer Science". University of California at Davis. Retrieved on August, 2(2009), 1-33.

Mert, H. ve Tas, O. (2019). “An application of artificial intelligence on auditing”. Pressacademia, 9(9), 65-68. doi:10.17261/Pressacademia.2019.1067

Ministry of Treasury and Finance, (2021, 13 January). “Number of Full-Empty Internal Auditors Cadre”, https://www.hmb.gov.tr/duyuru/idareler-itibariyleguncel-dolu-bos-ic-denetci-kadro-sayilari adresinden erişildi.

Kuluçlu, E. (2006). Yönetimin Denetiminden Denetimin Yönetimine [Management Control to The Management of The Audit]. Saylştay Dergisi, (63), 3-35.

KGK Independent Auditing Standard-540, (2020, 28 December). "Independent Audit of Accounting Estimates and Related Disclosures". Retrieved from https://www.kgk.gov.tr/Portalv2Uploads/files/Duyurular/v2/BDS/BDS\%20540_\%20kurum\%20sitesi.pdf

Öztürk, Y . (2014). Performans Denetimi Ve Türkiyede Uygulanabilirliği . Selçuk Üniversitesi Sosyal Bilimler Meslek Yüksekokulu Dergisi , 7 (1-2), $153-170$.

PWC. (2019). “International Financial Reporting Standards Bulletin, The Effect of Corona Virus on Accounting Practices", p. 17. Retrieved from https:// www.pwc.com.tr/tr/Hizmetlerimiz/denetim/ufrs-tfrs-raporlamasi/finansal-raporlama-standarti-tfrs-mart-2020.pdf

Seçkin, M., Seçkin, A. Ç. ve Coşkun, A. (2019). Production fault simulation and forecasting from time series data with machine learning in glove textile industry. Journal of Engineered Fibers and Fabrics, 14, 155892501988346. doi:10.1177/1558925019883462

Shamey, R. ve Hussain, T. (2003). Artificial intelligence in the colour and textile industry. Review of Progress in Coloration and Related Topics, 33, $33-45$.

Şavlı, T. (2011). Independent Audit Process within the Scope of International Audit Standards. International Accounting Symposium, Number. 10, Publication of Istanbul Chamber of Certified Public Accountants (ISMMMO) Yayın1, ss: 7-8. Retrieved from http://archive.ismmmo.org.tr/docs/ SEMPOZYUMLAR/SEMPOZYUM_10/sunumlar/TUBASAVLI.pdf

T.C. Presidential Legislation Information System, (2021, Ocak 22). Independent Audit Regulation, Official Gazette Number: 28509, Official Gazette Date: 26.12.2012, Retrieved from https://www.mevzuat.gov.tr/mevzuat?MevzuatNo=16907\&MevzuatTur=7\&MevzuatTertip=5

TÜRMOB, (2020b). The Impact of the Corona Epidemic on the Turkish Economy, Evaluations and Recommendations Report. TÜRMOB Publications503, p. 126.

TÜRMOB (Türkiye Serbest Muhasebeci Mali Müşavirler ve Yeminli Mali müşavirler Odaları Birliği), (2020a). COVID-19: Third Party Risks and Management. TÜRMOB Publications, p. 2. 
